\title{
Endoscopic Approach for Superficial Colorectal Neoplasms
}

\author{
Jun-feng $\mathrm{Xu}^{\mathrm{a}} \quad$ Lang Yang $^{\mathrm{b}} \quad$ Peng Jin $^{\mathrm{b}}$ Jian-qiu Sheng ${ }^{\mathrm{b}}$ \\ a People's Liberation Army General Hospital and ${ }^{b}$ Department of Gastroenterology, \\ PLA Army General Hospital, Beijing, China
}

\section{Key Words}

Early colorectal cancer - Endoscopic mucosal resection - Endoscopic submucosal dissection . Laterally spreading tumor

\begin{abstract}
Background: Colorectal cancer (CRC) is the third most commonly diagnosed cancer in males and the second in females, with an estimated 1.4 million cases and 693,900 deaths in 2012. Colonoscopy is the cornerstone for the detection and prevention of CRC. In addition, endoscopic treatment for CRC at an early stage can effectively improve patients' quality of life and cure rate. Summary: This review focuses on endoscopic approaches, including white light endoscopy, chromoendoscopy, magnifying endoscopy and therapeutic endoscopy, for the evaluation and treatment of superficial colorectal neoplasms. Key Message: Understanding the preoperative evaluation, indications and techniques of endoscopic mucosal resection/ endoscopic submucosal dissection as well as postoperative surveillance for superficial colorectal neoplasms is critical for providing appropriate management to the patients. Practical Implications: Endoscopic therapy, a method preserving organ function and improving quality of life, is a widely applied microinvasive treatment for superficial colorectal neoplasms. This review describes the basics and developments of endoscopic approaches and may facilitate daily practice for superficial colorectal neoplasms.

(c) 2016 S. Karger AG, Basel
\end{abstract}

\section{Introduction}

Colorectal cancer (CRC) is the third most common malignancy worldwide [1]. Colonoscopy is a widely accepted method for detecting and treating CRC at an early stage to decrease CRC incidence and mortality. Presently, superficial colorectal neoplasms, including 
precancerous lesions and early cancer, can be detected and evaluated by white light endoscopy, chromoendoscopy and magnifying endoscopy, and be resected by endoscopic mucosal resection (EMR) and endoscopic submucosal dissection (ESD), which are minimally invasive and have become the preferred choices. In this review, the basic and progressive knowledge, including the risks of lymph node metastasis, preoperative evaluation methods and therapeutic techniques for superficial colorectal neoplasms, are summarized.

\section{The Risks of Lymph Node Metastasis}

Endoscopic resection requires lesions with a limited risk of lymph node metastasis. Accumulating evidence has demonstrated that tumor size, invasion depth, lymphovascular invasion, tumor budding, and histological tumor grade are associated with lymph node metastasis. Although those risk factors are related to lymph node metastasis, only a few factors can be predicted currently before resection.

\section{Depth of Invasion}

Tumors limited to the mucosal layer have a negligible risk of lymph node metastasis [2]. Presently, at least two classification systems exist to predict lymph node metastasis. The Kikuchi classification system is used for non-polypoid lesions and divides the submucosa into three layers: $\mathrm{sm} 1=$ the upper third of the submucosa, $\mathrm{sm} 2=$ the middle third of the submucosa, and sm3 = the lower third of the submucosa (fig. 1) [3]. The frequency of lymph node metastasis for sm 1 and sm 2 has been reported to be 2 and $8 \%$ [4], and the risk of lymph node metastasis for sm3 has been described to be $12-25 \%$ [5].

Haggitt's classification is applicable in pedunculated polypoid lesions and defines the depth of invasion according to the following criteria: level $1=$ carcinoma invading through the muscularis mucosae but limited to the head of the polyp, level 2 = carcinoma invading to the level of the neck (the junction of the head and stalk), level $3=$ carcinoma invading any part of the stalk, and level 4 = carcinoma invading into the submucosa of the bowel wall below the level of the stalk but above the muscularis propria (fig. 2) [3]. Many studies have shown that the ratio of nodal metastasis is $<1 \%$ for polyps with a Haggitt level 1,2 or 3 [6, 7]. A recent retrospective multicenter study reported that the frequency of lymph node metastasis was $0.0 \%$ when tumor cell infiltration was limited to the head of the polyp, while the rate of lymph node metastasis increased to $6.2 \%$ once the tumor cells extended into the neck of the polyp [8]. In addition, Ueno et al. [9] set another standard to measured invasion and found that the lymph node metastatic potential was 2.5 vs. $18.2 \%$ when submucosal invasion width was less or more than $4,000 \mu \mathrm{m}$, and 3.9 vs. $17.1 \%$ when submucosal invasion depth was less or more than $2,000 \mu \mathrm{m}$.

\section{Tumor Size/Macroscopic Morphology}

Tumors with larger size have a higher risk of submucosal invasion. The frequency of submucosal invasion is $<1 \%$ when the lesion size is $<1.0 \mathrm{~cm}$. However, the rate of submucosal invasion reaches $30 \%$ when the diameter is $>2.0 \mathrm{~cm}$ in polypoid lesions (type 0 -Ip or 0-Is) [10]. Laterally spreading tumors (LST) are classified into granular type (LST-G) and nongranular type (LST-NG). Yamada et al. [11] reported that submucosal invasion was detected in 159 of 408 LST-NG cases (39\%) and that in 54\% of those 159 cases invasion was deep $(\geq 1,000 \mu \mathrm{m})$. The presence of a submucosal mass-like elevation, depression, and invasive pit pattern were risk factors for deep submucosal invasion, while submucosal invasion was detected in 80 of 414 LST-G cases (19\%), 79\% of those 80 cases showing deep invasion. Risk factors for deep submucosal invasion were the presence of a large nodule, depression, and 
Fig. 1. Kikuchi levels of invasion in sessile (non-polypoid) submucosal invasive cancers (pT1 adenocarcinomas).

Fig. 2. Haggitt levels of invasion in pedunculated (polypoid) submucosal invasive cancers (pT1 adenocarcinomas).
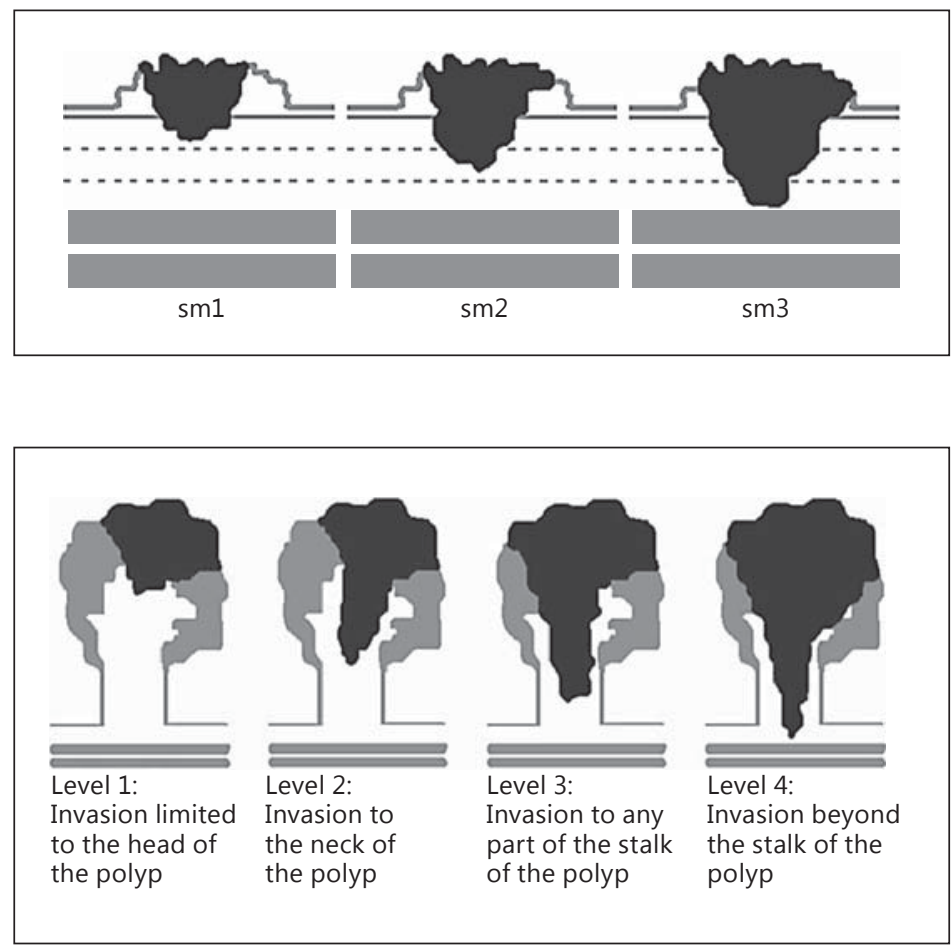

invasive pit pattern [11]. However, Uraoka et al. [12] revealed that the possibility of submucosal invasion was about 14\% in LST-NG lesions and that the existence of sclerous wall change, invasive pattern, and larger tumor size $(>20 \mathrm{~mm})$ were independent risk factors. In addition, LST-G lesions with a low rate $(7 \%)$ of submucosal invasion are generally observed below the largest nodule or depression, which can be used to predict submucosal invasion before endoscopic treatment [12].

\section{Preoperative Evaluation of Lesions}

\section{Conventional Endoscopy with White Light Imaging}

Tumor invasion depth was related to the macromorphology of the lesion, such as tumor size, loss of lobulation, excavation, stalk swelling, demarcated depressed area, fullness and fold convergence. Different endoscopic factors have been assessed for each type: 'stalk swelling' for only the pedunculated type, 'loss of lobulation' and 'excavation' for the pedunculated and sessile types, 'fullness' and 'fold convergence' for the superficial type, and 'size' and 'demarcated depressed area' for all three types. A retrospective study showed that the overall accuracy for differentiating intramucosal or slight submucosal invasion (sm1 invasion) from deep submucosal invasion ( $\mathrm{sm} 2$ invasion or deeper) is $84.2 \%$ in the pedunculated type, $88.6 \%$ in the sessile type and $92.5 \%$ in the superficial type [13].

\section{Magnifying Chromoendoscopy}

High-magnification observation with indigo carmine dye can be used to characterize lesions based on pit patterns (types I-V, Kudo classification). Presently, the type $V$ pit pattern is subclassified into type $V_{I}$ and type $V_{N}$. Type $V_{I}$ is an index of adenoma with severe dysplasia or sm1 carcinoma, while type $V_{N}$ is an indicator of invasion more than sm1 [14]. To date, several trials have demonstrated that Kudo's pit pattern classification is a highly accurate 
diagnostic method in differentiating neoplastic from non-neoplastic lesions. Recently, a metaanalysis showed that pooled sensitivity is $89.0 \%$ and specificity $85.7 \%$ for the diagnosis of colorectal neoplastic polyps [15].

\section{Narrow-Band Imaging}

Narrow-band imaging is an optical imaging technology which can enhance real-time visualization of the mucosal surface structure and vascular pattern ad is able to determine whether the lesion is tumorous or non-tumorous, as well as what is its invasion depth. Sano classified the capillary pattern (CP) as type I, II, IIIA and IIIB on the basis of its visibility, caliber variation, tortuosity, and stoppage. CP type IIIB is correlated with deep submucosal invasive carcinomas [14]. Ikematsu et al. [16] reported that the sensitivity and specificity of CP types IIIA and IIIB in differentiating intramucosal or slight submucosal invasion from deep submucosal invasion is 84.8 and $88.7 \%$, respectively. Moreover, the Narrow-Band Imaging International Colorectal Endoscopic (NICE) classification has been recently developed and validated to allow endoscopic prediction of colorectal polyp histology and differentiation between hyper plastic (type 1) and adenomatous (type 2) colorectal polyps, the overall accuracy being $75 \%$ and the overall negative predictive value $85 \%$ [17]. A limitation of the NICE classification is that it does not specifically incorporate sessile serrated adenomas into the classification.

\section{Endoscopic Ultrasonography}

Endoscopic ultrasonography can be used to stage rectal epithelial lesions. A previous study showed that endoscopic ultrasonography had higher diagnostic accuracy than pit patterns based on magnifying endoscopy in T staging [18], whereas another study found that the diagnostic accuracy of those methods was similar [19]. Recently, Mukae et al. [20] found that the sensitivity and specificity of endoscopic ultrasonography in estimating the deep invasion depth of early CRC was 90 and $87 \%$, respectively.

\section{Non-Lifting Sign}

The non-lifting sign, first reported by Uno and Munakata [21], is useful to predict the depth of carcinoma invasion and is widely used in clinical practice. One multicenter study observed that the sensitivity and specificity of non-lifting sign versus conventional colonoscopy are 61.5 vs. $84.6 \%$ and 98.4 vs. $98.8 \%$, respectively [22]. Thus, the non-lifting sign should not be accepted to assess invasion depth for its lower sensitivity and accuracy. However, this sign can be used to predict technically difficulties. In addition, superficial colorectal tumors exhibiting a positive non-lifting sign may result from peristaltic motion or fibrosis caused by biopsy, so once the lesion is diagnosed as superficial carcinoma, biopsy should be avoided.

\section{Confocal Laser Endomicroscopy}

Confocal laser endomicroscopy has emerged as a valuable tool for gastrointestinal endoscopic imaging since its introduction in 2004. As an in vivo virtual biopsy technique, confocal laser endomicroscopy allows real-time histological diagnosis free from conventional biopsy. It has been proven to have high sensitivity and specificity in the diagnosis of colorectal neoplasia. Xie et al. [23] reported that the sensitivity and specificity of real-time confocal laser endomicroscopy in identifying colonic adenomas were 93.9 and $95.9 \%$, compared with histological results. A recent meta-analysis including 11 studies revealed that confocal laser endomicroscopy has a high diagnostic accuracy for neoplastic and non-neoplastic colonic lesions [24]. 


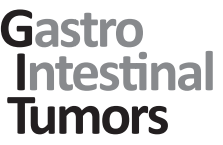

Table 1. Indications for colorectal endoscopic treatment $[51,52]$

\begin{tabular}{l|l}
\hline Gastrointest Tumors 2016;3:69-80 \\
\hline DOI: 10.1159/000447128 & $\begin{array}{l}\text { @ 2016 S. Karger AG, Basel } \\
\text { www.karger.com/gat }\end{array}$ \\
\hline
\end{tabular}

Xu et al.: Endoscopic Approach for Superficial Colorectal Neoplasms

\section{EMR}

1 5- to 20-mm flat lesions

2 Sessile lesions (Is, >10 mm) suspected to be villous adenoma or sessile serrated adenoma/polyp

3 Suspicious high-grade intraepithelial neoplasia or slight submucosal invasion lesions ( $\leq 20 \mathrm{~mm}$ ) expected to be able to complete resection by EMR

EPMR

1 20- to 30-mm LST-G-type lesions

2 Large LST lesions ( $>30 \mathrm{~mm}$, hospital without ESD technology)

\section{ESD}

1 Large ( $>20 \mathrm{~mm}$ ) lesion amenable to endoscopic treatment in which en bloc EMR resection is difficult.

- LST-NG >20 mm, particularly LST-NG (PD)

- $\quad$ LST-G >30 mm

- Lesions showing a VI-type pit pattern

- Carcinoma with shallow T1 (submucosal) invasion

- Large depressed-type tumors

- Large protruded-type lesions suspected to be carcinoma

2 Mucosal tumors with submucosal fibrosis

3 Sporadic localized tumors in conditions of chronic inflammation such as ulcerative colitis

4 Local residual or recurrent early carcinomas after endoscopic resection

\section{Technical Aspects of Endoscopic Approaches for Early CRC}

\section{Indications and Contraindications for Colorectal Endoscopic Treatment}

Endoscopic resection of superficial tumor requires limited risk of lymph node metastasis and feasibility of en bloc resection. Indications for colorectal endoscopic treatment are presented in table 1 , contraindications in table 2.

\section{Bowel Preparation}

Excellent bowel preparation is critical for the detection of precancerous lesions or early CRC. Besides, it is a key element in avoiding adverse events such as bacterial peritonitis following iatrogenic colonic perforation. In our hospital, patients typically receive split use of 2 liters of polyethylene glycol, the first time on the night before the procedure, the second in the morning prior to EMR/ESD.

\section{Carbon Dioxide Insufflation}

The efficacy of carbon dioxide insufflation during endoscopic procedures has been emphasized in recent years. It is reported that patient discomfort is considerably lower in the carbon dioxide group, probably because of a more rapid absorption of carbon dioxide than under conventional air insufflation. Increasing evidence revealed that carbon dioxide insufflation reduces pain to the patient and the risk of pneumoperitoneum in case of perforation as well as the occurrence of abdominal complaints [26].

\section{Submucosal Injection}

The maintenance of adequate submucosal elevation by injection is a key component influencing EMR/ESD procedures. An optimal injection solution should (1) achieve and 


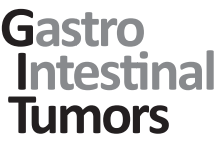

Table 2. Contraindications for colorectal endoscopic treatment [52]

\begin{tabular}{l|l}
\hline Gastrointest Tumors 2016;3:69-80 \\
\hline DOI: 10.1159/000447128 & $\begin{array}{l}\text { @ 2016 S. Karger AG, Basel } \\
\text { www.karger.com/gat }\end{array}$ \\
\hline
\end{tabular}

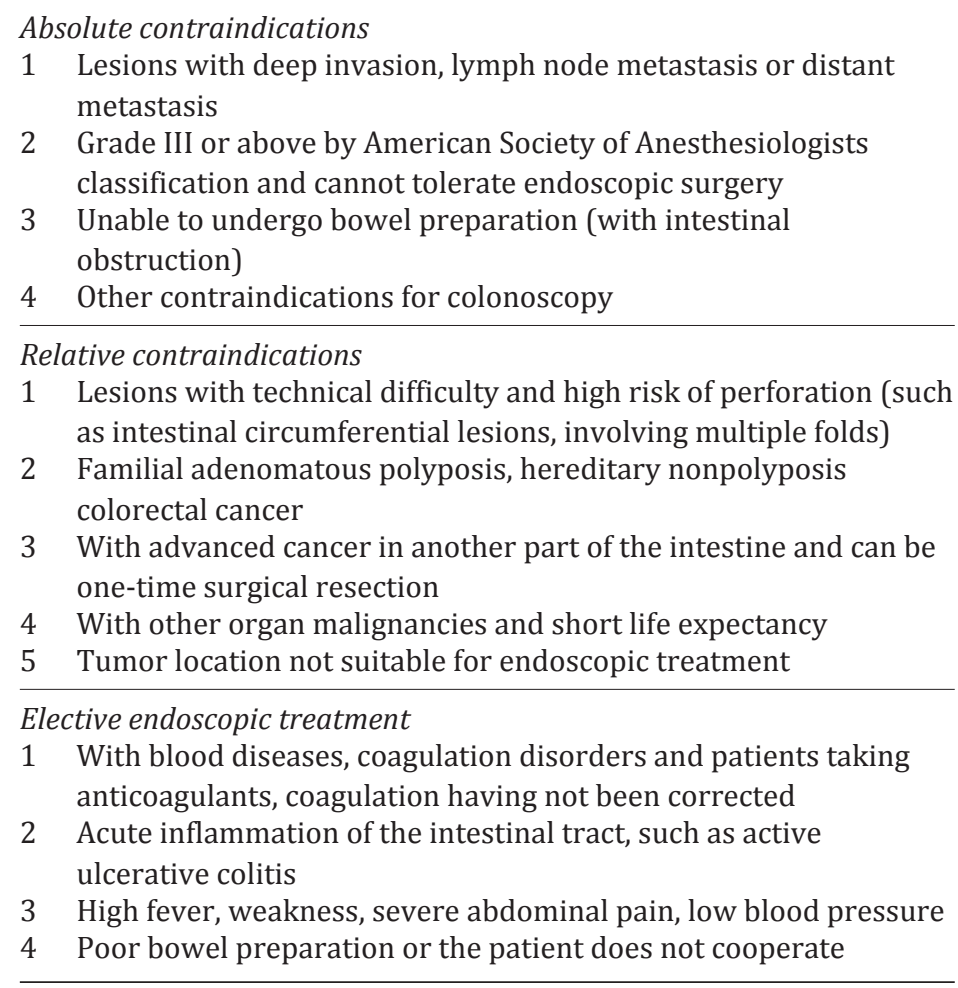

Absolute contraindications metastasis

Grade III or above by American Society of Anesthesiologists

Unable to undergo bowel preparation (with intestinal obstruction)

Other contraindications for colonoscopy

Relative contraindications

Familial adenomatous polyposis, hereditary nonpolyposis colorectal cancer

one-time surgical resection

4 With other organ malignancies and short life expectancy

Tumor location not suitable for endoscopic treatment

Elective endoscopic treatment

With blood diseases, coagulation disorders and patients taking anticoagulants, coagulation having not been corrected

(tract, such as active

Poor bowel preparation or the patient does not cooperate

maintain the necessary submucosal lifting height and duration [27], (2) not influence the histological evaluation, and (3) be easily prepared with low cost and no toxicity [28]. Currently, various submucosal injection solutions have been developed, including normal saline, fibrinogen mixture, dextrose, glycerol, sodium hyaluronic acid, succinylated gelatin, hydroxyethyl starch, and mesna. One meta-analysis showed that, compared with normal saline, other submucosal injection solutions have a significant increase in terms of en bloc resection rate (82 vs. $77 \%$ ) and complete resection rate ( 89 vs. $79 \%$ ). However, there was no significant difference in the incidence of total complications [29].

\section{Techniques of EMR/ESD}

EMR is broadly divided into two basic types: non-suction method (submucosal injectionresection) and suction method (transparent cap method and ligation method). In colorectal EMR, the submucosal injection-resection technique is often used, while the transparent cap or ligation technique is rarely used for smaller tumors and associated with the risk of perforation. The injection should elevate the lesion into the lumen and toward the colonoscopy to improve access. Excessive injection should be avoided because this may hinder adequate visualization and create excessive tension within the cushion, which makes snare capture of adequate tissue challenging.

The endoscopic piecemeal mucosal resection (EPMR) technique can be applied for large flat lesions $(>2 \mathrm{~cm})$, dividing the lesion into several parts and removing it in several steps. When using EPMR for LST-G (mixed) type lesions, the large nodule $(\geq 1 \mathrm{~cm})$ should be resected en bloc first, then the remaining lesions should be removed. During this process, the number of piecemeal specimens must be controlled, because it is difficult to splice tissue specimens for accurate pathological assessment. Besides, a higher number of resected specimens might be associated with a higher risk of local residues/recurrence, so careful colonoscopic surveillance is needed after EPMR [30]. 
ESD enables direct submucosal dissection, so that early-stage gastrointestinal tumors can be removed with a high en bloc resection rate, and is not limited by lesion size or location. ESD also enables detailed histological evaluation of the specimen and accurate judgment of resection margins. Procedures of colorectal ESD are primarily performed using ESD knives, including a bipolar needle knife, Flex/Dual knife, Hook knife, IT knife, Flush knife and SB knife. The selection of ESD knives is depended on the operator's experience and the type of colorectal neoplasia. After submucosal injection with glycerol and/or sodium hyaluronate, a circumferential incision is made using the ESD knife. Both partial circumferential incision and subsequent submucosal dissection are performed alternately.

Colorectal ESD is technically difficult because of the anatomical features of the colon such as the thin walls, folds and flexures, and colonic peristalsis. This technical difficulty is likely to be associated with complications, especially perforation. Previous studies used long procedure times (more than 120 or $150 \mathrm{~min}$ ); perforation and piecemeal resection mark the technical difficulty of colorectal ESD, and it was found that technical difficulty was associated with factors including mobility of tumor location (mobile: sigmoid or transverse colon; fixed: rectum, descending colon, ascending colon, or cecum), lesions at a fold or flexure, huge tumor ( $\geq 5$ or $\geq 4 \mathrm{~cm}$ ), tumors associated with scarring or local recurrence (presence of severe fibrosis) [31-33]. In recent years, in order to obtain adequate tissue tension and clear visibility of the tissue, reduce operating time and improve security, many ESD-assisted methods have been developed, such as the clip-with-line method, the sinker-assisted method, the internal traction method, the outer route method, the double-scope method, the external forceps method and the endoscopic surgical platform [34].

\section{Complications}

The complications associated with EMR/ESD procedures, including perforation, bleeding and post-polypectomy electrocoagulation syndrome, are listed in table 3.

\section{Histological Assessment}

Curability is evaluated based on the tumor margin of the resected specimen and risk factors for lymph node/distant metastasis. Mucosal (Tis) carcinomas can be radically cured by endoscopic local resection without risk of metastasis. For T1 (submucosal) carcinomas, additional surgery should be carried out in cases with positive vertical tumor margin, submucosal invasion depth $>1,000 \mu \mathrm{m}$, vascular or lymphatic invasion, poorly differentiated or undifferentiated adenocarcinoma, signet ring cell carcinoma or mucinous carcinoma, or tumor budding grade 2 or 3 in the deepest part of infiltration [35, 36]. Application of immunohistochemistry for D2-40 and desmin is informative to accurately detect vascular invasion and depth of submucosal invasion. Two large-scale retrospective multicenter cohort studies have shown that for patients with submucosal invasive CRC without the above risk factors, the 5-year overall survival rates were similar whether they were treated by endoscopic resection alone or underwent endoscopic resection with subsequent surgery [37, 38].

\section{Postoperative Follow-Up}

En Bloc Resection Rates of Colorectal EMR/ESD

En bloc resection is desirable as an endoscopic treatment for early CRC. The en bloc resection rate of colorectal EMR is 31.0-66.3\%, the complete histological resection rate being 
Table 3. Complications of colorectal endoscopic treatment

\begin{tabular}{|c|c|c|c|}
\hline Complications & $\begin{array}{l}\text { Incidence rate, } \\
\%\end{array}$ & Risk factors & Management methods \\
\hline $\begin{array}{l}\text { Perforation } \\
{[42,46,53,54]}\end{array}$ & $\begin{array}{l}\text { EMR: }<1.5 \\
\text { ESD: } 0.58-20.4\end{array}$ & $\begin{array}{l}\text { tumor size, large LST lesions, } \\
\text { presence of fibrosis }\end{array}$ & $\begin{array}{l}\text { titanium clip, loop clip, } \\
\text { over-the-scope clip }\end{array}$ \\
\hline $\begin{array}{l}\text { Delayed } \\
\text { perforation } \\
{[55-57]}\end{array}$ & $\begin{array}{l}\text { EMR: } 1.4-1.7 \\
\text { ESD: } 1.5-2.8\end{array}$ & $\begin{array}{l}\text { excessive coagulation in the } \\
\text { muscularis propria }\end{array}$ & emergency surgery \\
\hline $\begin{array}{l}\text { Bleeding } \\
{[43,58-62]}\end{array}$ & $\begin{array}{l}\text { EMR: } 1.0-18.0 \\
\text { ESD: } 0-15.6\end{array}$ & $\begin{array}{l}\text { right-sided lesions, older patient, } \\
\text { large tumor size, } 0 \text {-IIa+ Is lesions, } \\
\text { lesions containing villous } \\
\text { component, recent aspirin or } \\
\text { anticoagulation use, inadequate } \\
\text { experience of operators }\end{array}$ & $\begin{array}{l}\text { injection of epinephrine, } \\
\text { argon plasma coagulation, } \\
\text { coagulation graspers, } \\
\text { endoscopic application of } \\
\text { clips, snare tip soft } \\
\text { coagulation, contact } \\
\text { coagulation with the tip of } \\
\text { a knife, coagulation with } \\
\text { hemostatic forceps }\end{array}$ \\
\hline $\begin{array}{l}\text { Delayed bleeding } \\
{[47,58,59,61} \\
63-65]\end{array}$ & $\begin{array}{l}\text { EMR: } 0.2-7.2 \\
\text { ESD: } 0-12.5\end{array}$ & $\begin{array}{l}\text { location of lesions in the rectum/ } \\
\text { cecum, significant bleeding during } \\
\text { the process }\end{array}$ & $\begin{array}{l}\text { postoperative blood } \\
\text { pressure control, } \\
\text { prophylactic clip }\end{array}$ \\
\hline $\begin{array}{l}\text { Post-polypectomy } \\
\text { electrocoagulation } \\
\text { syndrome [66-68] }\end{array}$ & $1-8$ & $\begin{array}{l}\text { large tumor size, hypertension, } \\
\text { tumor site other than } \\
\text { rectosigmoid, non-polypoid } \\
\text { configuration of the lesion }\end{array}$ & $\begin{array}{l}\text { broad-spectrum antibiotics } \\
\text { (intravenous), fasting until } \\
\text { the symptoms disappear, } \\
\text { emergency surgery }\end{array}$ \\
\hline
\end{tabular}

$45.0 \%[39,40]$. However, the en bloc resection rate of colorectal ESD is significantly higher than that of EMR, which can reach 64-7\% [41]. The complete R0 resection rates of colorectal ESD also have a good performance, which can reach up to 53-91\% [41].

\section{Local Residual/Recurrence}

Residual lesions are among the 'seeds' of interval cancer, and colonoscopy surveillance is desirable for early detection of local recurrence. The recurrence rate of conventional colorectal EMR has been described to be $0.8-7.2 \%$, and the ratio is higher for larger lesions [42-45]. The local residual/recurrence rate for difficult cases can even be up to 20.4-27.0\% $[46,47]$. A recent meta-analysis reported that the mean risk of recurrence after EMR of nonpedunculated colorectal lesions is 15\%, occurring in 3\% of en bloc resections and $20 \%$ of piecemeal resections [39]. In addition, more than 5 piecemeal specimens is an independent risk factor for local recurrence after multiple EPMR [30]. Compared with the EMR group, the local recurrence rate is lower in the ESD group, accounting for $0.1-7.0 \%$ [30, 41]. A multicenter prospective study showed that piecemeal resection is the only significant factor associated with local recurrence in ESD [48].

\section{Surveillance Strategy after Endoscopic Treatment}

Surveillance improves the patient's prognosis by early detection and treatment of residual and recurrent lesions. Presently, it is recommended to perform a colonoscopy 6 and 12 months after definitive endoscopic resection of an early-stage carcinoma, and then colonoscopy surveillance yearly. A recent meta-analysis suggested that a follow-up colonoscopy 
should be done 6 months after colorectal EPMR [39]. Recommendations made by other studies show that 4 and 12 months are appropriate intervals for first and second surveillance colonoscopy [49]. Generally, for piecemeal resection cases, the colonoscopy should be performed between 3 and 6 months, with regard to the risk factors of recurrence such as size, location, and histological type of the lesion [50].

\section{Future Directions}

With the rapid development of endoscopic technology, endoscopic diagnosis and therapy for superficial neoplasm has been established in the last years. However, it is still a challenge to avoid missing lesions during colonoscopy, or to exclude lesions with indications of high risk of lymph node metastasis, including lymphovascular involvement and poor differentiation, before resection. Besides, full-thickness resection may be applied for submucosal cancer without lymph node metastasis. In the future, accurate endoscopic diagnosis of lymph node metastasis will be the cornerstone of lesion selection for therapy and permit real-time stratification of lesions and allocation to appropriate therapy. Besides, rapid advancements in devices and techniques, such as natural orifice transluminal endoscopic surgery and robotic endoscopy (MASTER), promise to facilitate safer procedures and to expand indications. Thus, colorectal endoscopic techniques will help us to achieve the goal of minimally invasive treatment for early CRC patients.

\section{Acknowledgments}

This work was supported by the National High-Tech R\&D Program of China (No. SS2014AA020803). We thank professor Zhijie Chang, State Key Laboratory of Biomembrane and Membrane Biotechnology, School of Medicine, Tsinghua University, for manuscript revision.

\section{Disclosure Statement}

The authors declare that they have no conflict of interest.

\section{References}

$>1$ Torre LA, Bray F, Siegel RL, Ferlay J, Lortet-Tieulent J, Jemal A: Global cancer statistics, 2012. CA Cancer J Clin 2015;65:87-108.

-2 Morson BC, Whiteway JE, Jones EA, Macrae FA, Williams CB: Histopathology and prognosis of malignant colorectal polyps treated by endoscopic polypectomy. Gut 1984;25:437-444.

-3 Resch A, Langner C: Risk assessment in early colorectal cancer: histological and molecular markers. Dig Dis 2015;33:77-85.

4 Nascimbeni R, Burgart LJ, Nivatvongs S, Larson DR: Risk of lymph node metastasis in T1 carcinoma of the colon and rectum. Dis Colon Rectum 2002;45:200-206.

5 Ramirez M, Schierling S, Papaconstantinou HT, Thomas JS: Management of the malignant polyp. Clin Colon Rectal Surg 2008;21:286-290.

6 Haggitt RC, Glotzbach RE, Soffer EE, Wruble LD: Prognostic factors in colorectal carcinomas arising in adenomas: implications for lesions removed by endoscopic polypectomy. Gastroenterology 1985;89:328336.

7 Nivatvongs S: Surgical management of malignant colorectal polyps. Surg Clin North Am 2002;82:959-966.

-8 Matsuda T, Fukuzawa M, Uraoka T, Nishi M, Yamaguchi Y, Kobayashi N, Ikematsu H, Saito Y, Nakajima T, Fujii T, Murakami Y, Shimoda T, Kushima R, Fujimori T: Risk of lymph node metastasis in patients with pedunculated type early invasive colorectal cancer: a retrospective multicenter study. Cancer Sci 2011;102:16931697. 
-9 Ueno H, Mochizuki H, Hashiguchi Y, Shimazaki H, Aida S, Hase K, Matsukuma S, Kanai T, Kurihara H, Ozawa K, Yoshimura K, Bekku S: Risk factors for an adverse outcome in early invasive colorectal carcinoma. Gastroenterology 2004;127:385-394.

$\checkmark 10$ The Paris endoscopic classification of superficial neoplastic lesions: esophagus, stomach, and colon: November 30 to December 1, 2002. Gastrointest Endosc 2003;58(6 suppl):S3-S43.

-11 Yamada M, Saito Y, Sakamoto T, Nakajima T, Kushima R, Parra-Blanco A, Matsuda T: Endoscopic predictors of deep submucosal invasion in colorectal laterally spreading tumors. Endoscopy 2016;48:456-464.

-12 Uraoka T, Saito Y, Matsuda T, Ikehara H, Gotoda T, Saito D, Fujii T: Endoscopic indications for endoscopic mucosal resection of laterally spreading tumours in the colorectum. Gut 2006;55:1592-1597.

13 Ikehara H, Saito Y, Matsuda T, Uraoka T, Murakami Y: Diagnosis of depth of invasion for early colorectal cancer using magnifying colonoscopy. J Gastroenterol Hepatol 2010;25:905-912.

14 Tanaka S, Hayashi N, Oka S, Chayama K: Endoscopic assessment of colorectal cancer with superficial or deep submucosal invasion using magnifying colonoscopy. Clin Endosc 2013;46:138-146.

-15 Li M, Ali SM, Umm-a-OmarahGilani S, Liu J, Li YQ, Zuo XL: Kudo's pit pattern classification for colorectal neoplasms: a meta-analysis. World J Gastroenterol 2014;20:12649-12656.

-16 Ikematsu H, Matsuda T, Emura F, Saito Y, Uraoka T, Fu KI, Kaneko K, Ochiai A, Fujimori T, Sano Y: Efficacy of capillary pattern type IIIA/IIIB by magnifying narrow band imaging for estimating depth of invasion of early colorectal neoplasms. BMC Gastroenterol 2010;10:33.

-17 Hayashi N, Tanaka S, Hewett DG, Kaltenbach TR, Sano Y, Ponchon T, Saunders BP, Rex DK, Soetikno RM: Endoscopic prediction of deep submucosal invasive carcinoma: validation of the narrow-band imaging international colorectal endoscopic (NICE) classification. Gastrointest Endosc 2013;78:625-632.

18 Hurlstone DP, Brown S, Cross SS, Shorthouse AJ, Sanders DS: High magnification chromoscopic colonoscopy or high frequency $20 \mathrm{MHz}$ mini probe endoscopic ultrasound staging for early colorectal neoplasia: a comparative prospective analysis. Gut 2005;54:1585-1589.

19 Fu KI, Kato S, Sano Y, Onuma EK, Saito Y, Matsuda T, Koba I, Yoshida S, Fujii T: Staging of early colorectal cancers: magnifying colonoscopy versus endoscopic ultrasonography for estimation of depth of invasion. Dig Dis Sci 2008;53:1886-1892.

-20 Mukae M, Kobayashi K, Sada M, Yokoyama K, Koizumi W, Saegusa M: Diagnostic performance of EUS for evaluating the invasion depth of early colorectal cancers. Gastrointest Endosc 2015;81:682-690. Uno Y, Munakata A: The non-lifting sign of invasive colon cancer. Gastrointest Endosc 1994;40:485-489.

22 Kobayashi N, Saito Y, Sano Y, Uragami N, Michita T, Nasu J, Matsuda T, Fu KI, Fujii T, Fujimori T, Ishikawa T, Saito D: Determining the treatment strategy for colorectal neoplastic lesions: endoscopic assessment or the non-lifting sign for diagnosing invasion depth? Endoscopy 2007;39:701-705.

23 Xie XJ, Li CQ, Zuo XL, Yu T, Gu XM, Li Z, Ji R, Wang Q, Li YQ: Differentiation of colonic polyps by confocal laser endomicroscopy. Endoscopy 2011;43:87-93.

24 Wanders LK, East JE, Uitentuis SE, Leeflang MM, Dekker E: Diagnostic performance of narrowed spectrum endoscopy, autofluorescence imaging, and confocal laser endomicroscopy for optical diagnosis of colonic polyps: a meta-analysis. Lancet Oncol 2013;14:1337-1347.

25 Saito Y, Uraoka T, Matsuda T, Emura F, Ikehara H, Mashimo Y, Kikuchi T, Kozu T, Saito D: A pilot study to assess the safety and efficacy of carbon dioxide insufflation during colorectal endoscopic submucosal dissection with the patient under conscious sedation. Gastrointest Endosc 2007;65:537-542.

26 Shinozaki S, Hayashi Y, Lefor AK, Yamamoto H: What is the best therapeutic strategy for colonoscopy of colorectal neoplasia? Future perspectives from the East. Dig Endosc 2016;28:289-295.

27 Uraoka T, Saito Y, Yamamoto K, Fujii T: Submucosal injection solution for gastrointestinal tract endoscopic mucosal resection and endoscopic submucosal dissection. Drug Des Devel Ther 2009;2:131-138.

-28 Fujishiro M, Yahagi N, Kashimura K, Matsuura T, Nakamura M, Kakushima N, Kodashima S, Ono S, Kobayashi K, Hashimoto T, Yamamichi N, Tateishi A, Shimizu Y, Oka M, Ichinose M, Omata M: Tissue damage of different submucosal injection solutions for EMR. Gastrointest Endosc 2005;62:933-942.

29 Huai ZY, Feng Xian W, Chang Jiang L, Xi Chen W: Submucosal injection solution for endoscopic resection in gastrointestinal tract: a traditional and network meta-analysis. Gastroenterol Res Pract 2015;2015:702768.

-30 Sakamoto T, Matsuda T, Otake Y, Nakajima T, Saito Y: Predictive factors of local recurrence after endoscopic piecemeal mucosal resection. J Gastroenterol 2012;47:635-640.

-31 Sato K, Ito S, Kitagawa T, Kato M, Tominaga K, Suzuki T, Maetani I: Factors affecting the technical difficulty and clinical outcome of endoscopic submucosal dissection for colorectal tumors. Surg Endosc 2014;28:29592965.

-32 Hori K, Uraoka T, Harada K, Higashi R, Kawahara Y, Okada H, Ramberan H, Yahagi N, Yamamoto K: Predictive factors for technically difficult endoscopic submucosal dissection in the colorectum. Endoscopy 2014;46:862870.

33 Mizushima T, Kato M, Iwanaga I, Sato F, Kubo K, Ehira N, Uebayashi M, Ono S, Nakagawa M, Mabe K, Shimizu Y, Sakamoto N: Technical difficulty according to location, and risk factors for perforation, in endoscopic submucosal dissection of colorectal tumors. Surg Endosc 2015;29:133-139.

-34 Imaeda H, Hosoe N, Kashiwagi K, Ohmori T, Yahagi N, Kanai T, Ogata H: Advanced endoscopic submucosal dissection with traction. World J Gastrointest Endosc 2014;6:286-295. 
-35 Watanabe T, Itabashi M, Shimada Y, Tanaka S, Ito Y, Ajioka Y, Hamaguchi T, Hyodo I, Igarashi M, Ishida H, Ishiguro M, Kanemitsu Y, Kokudo N, Muro K, Ochiai A, Oguchi M, Ohkura Y, Saito Y, Sakai Y, Ueno H, Yoshino T, Fujimori T, Koinuma N, Morita T, Nishimura G, Sakata Y, Takahashi K, Takiuchi H, Tsuruta O, Yamaguchi T, Yoshida M, Yamaguchi N, Kotake K, Sugihara K: Japanese Society for Cancer of the Colon and Rectum (JSCCR) guidelines 2010 for the treatment of colorectal cancer. Int J Clin Oncol 2012;17:1-29.

-36 Tanaka S, Asayama N, Shigita K, Hayashi N, Oka S, Chayama K: Towards safer and appropriate application of endoscopic submucosal dissection for T1 colorectal carcinoma as total excisional biopsy: future perspective. Dig Endosc 2015;27:216-222.

37 Ikematsu H, Yoda Y, Matsuda T, Yamaguchi Y, Hotta K, Kobayashi N, Fujii T, Oono Y, Sakamoto T, Nakajima T, Takao M, Shinohara T, Murakami Y, Fujimori T, Kaneko K, Saito Y: Long-term outcomes after resection for submucosal invasive colorectal cancers. Gastroenterology 2013;144:551-559.

38 Yoda Y, Ikematsu H, Matsuda T, Yamaguchi Y, Hotta K, Kobayashi N, Fujii T, Oono Y, Sakamoto T, Nakajima T, Takao M, Shinohara T, Fujimori T, Kaneko K, Saito Y: A large-scale multicenter study of long-term outcomes after endoscopic resection for submucosal invasive colorectal cancer. Endoscopy 2013;45:718-724.

39 Belderbos TD, Leenders M, Moons LM, Siersema PD: Local recurrence after endoscopic mucosal resection of nonpedunculated colorectal lesions: systematic review and meta-analysis. Endoscopy 2014;46:388-402.

40 Hong YM, Kim HW, Park SB, Choi CW, Kang DH: Endoscopic mucosal resection with circumferential incision for the treatment of large sessile polyps and laterally spreading tumors of the colorectum. Clin Endosc 2015; 48:52-58.

41 Pimentel-Nunes P, Dinis-Ribeiro M, Ponchon T, Repici A, Vieth M, De Ceglie A, Amato A, Berr F, Bhandari P, Bialek A, Conio M, Haringsma J, Langner C, Meisner S, Messmann H, Morino M, Neuhaus H, Piessevaux H, Rugge M, Saunders BP, Robaszkiewicz M, Seewald S, Kashin S, Dumonceau JM, Hassan C, Deprez PH: Endoscopic submucosal dissection: European Society of Gastrointestinal Endoscopy (ESGE) Guideline. Endoscopy 2015; 47:829-854.

-42 Park JJ, Cheon JH, Kwon JE, Shin JK, Jeon SM, Bok HJ, Lee JH, Moon CM, Hong SP, Kim TI, Kim H, Kim WH: Clinical outcomes and factors related to resectability and curability of EMR for early colorectal cancer. Gastrointest Endosc 2011;74:1337-1346.

43 Kim HH, Kim JH, Park SJ, Park MI, Moon W: Risk factors for incomplete resection and complications in endoscopic mucosal resection for lateral spreading tumors. Dig Endosc 2012;24:259-266.

44 Kim MN, Kang JM, Yang JI, Kim BK, Im JP, Kim SG, Jung HC, Song IS, Kim JS: Clinical features and prognosis of early colorectal cancer treated by endoscopic mucosal resection. J Gastroenterol Hepatol 2011;26:16191625.

45 Mahadeva S, Rembacken BJ: Standard 'inject and cut' endoscopic mucosal resection technique is practical and effective in the management of superficial colorectal neoplasms. Surg Endosc 2009;23:417-422.

-46 Moss A, Bourke MJ, Williams SJ, Hourigan LF, Brown G, Tam W, Singh R, Zanati S, Chen RY, Byth K: Endoscopic mucosal resection outcomes and prediction of submucosal cancer from advanced colonic mucosal neoplasia. Gastroenterology 2011;140:1909-1918.

47 Buchner AM, Guarner-Argente C, Ginsberg GG: Outcomes of EMR of defiant colorectal lesions directed to an endoscopy referral center. Gastrointest Endosc 2012;76:255-263.

48 Oka S, Tanaka S, Saito Y, Iishi H, Kudo SE, Ikematsu H, Igarashi M, Saitoh Y, Inoue Y, Kobayashi K, Hisabe T, Tsuruta O, Sano Y, Yamano H, Shimizu S, Yahagi N, Watanabe T, Nakamura H, Fujii T, Ishikawa H, Sugihara K; Colorectal Endoscopic Resection Standardization Implementation Working Group of the Japanese Society for Cancer of the Colon and Rectum, Tokyo, Japan: Local recurrence after endoscopic resection for large colorectal neoplasia: a multicenter prospective study in Japan. Am J Gastroenterol 2015;110:697-707.

-49 Moss A, Williams SJ, Hourigan LF, Brown G, Tam W, Singh R, Zanati S, Burgess NG, Sonson R, Byth K, Bourke MJ: Long-term adenoma recurrence following wide-field endoscopic mucosal resection (WF-EMR) for advanced colonic mucosal neoplasia is infrequent: results and risk factors in 1000 cases from the Australian Colonic EMR (ACE) study. Gut 2015;64:57-65.

50 Winawer SJ, Zauber AG, Fletcher RH, Stillman JS, O’Brien MJ, Levin B, Smith RA, Lieberman DA, Burt RW, Levin TR, Bond JH, Brooks D, Byers T, Hyman N, Kirk L, Thorson A, Simmang C, Johnson D, Rex DK: Guidelines for colonoscopy surveillance after polypectomy: a consensus update by the US Multi-Society Task Force on Colorectal Cancer and the American Cancer Society. Gastroenterology 2006;130:1872-1885.

51 Tanaka S, Kashida H, Saito Y, Yahagi N, Yamano H, Saito S, Hisabe T, Yao T, Watanabe M, Yoshida M, Kudo SE, Tsuruta O, Sugihara K, Watanabe T, Saitoh Y, Igarashi M, Toyonaga T, Ajioka Y, Ichinose M, Matsui T, Sugita A, Sugano K, Fujimoto K, Tajiri H: JGES guidelines for colorectal endoscopic submucosal dissection/endoscopic mucosal resection. Dig Endosc 2015;27:417-434.

52 Bai Y, Yang F, Ma D, Zou WB: Zhong guo zao qi jie zhi chang ai shai cha ji nei jing zhen zhi zhi nan. Wei Chang Bing Xue 2015;95:345-365.

53 Kim ES, Cho KB, Park KS, Lee KI, Jang BK, Chung WJ, Hwang JS: Factors predictive of perforation during endoscopic submucosal dissection for the treatment of colorectal tumors. Endoscopy 2011;43:573-578.

54 Sohara N, Hagiwara S, Arai R, Iizuka H, Onozato Y, Kakizaki S: Can endoscopic submucosal dissection be safely performed in a smaller specialized clinic? World J Gastroenterol 2013;19:528-535.

55 Saito Y, Uraoka T, Yamaguchi Y, Hotta K, Sakamoto N, Ikematsu H, Fukuzawa M, Kobayashi N, Nasu J, Michida T, Yoshida S, Ikehara H, Otake Y, Nakajima T, Matsuda T, Saito D: A prospective, multicenter study of 1111 colorectal endoscopic submucosal dissections (with video). Gastrointest Endosc 2010;72:1217-1225. 
Nakajima T, Saito Y, Tanaka S, Iishi H, Kudo SE, Ikematsu H, Igarashi M, Saitoh Y, Inoue Y, Kobayashi K, Hisasbe T, Matsuda T, Ishikawa H, Sugihara K: Current status of endoscopic resection strategy for large, early colorectal neoplasia in Japan. Surg Endosc 2013;27:3262-3270.

57 Oka S, Tanaka S, Kanao H, Ishikawa H, Watanabe T, Igarashi M, Saito Y, Ikematsu H, Kobayashi K, Inoue Y, Yahagi N, Tsuda S, Simizu S, Iishi H, Yamano H, Kudo SE, Tsuruta O, Tamura S, Saito Y, Cho E, Fujii T, Sano Y, Nakamura H, Sugihara K, Muto T: Current status in the occurrence of postoperative bleeding, perforation and residual/local recurrence during colonoscopic treatment in Japan. Dig Endosc 2010;22:376-380.

58 Hurlstone DP, Cross SS, Drew K, Adam I, Shorthouse AJ, Brown S, Sanders DS, Lobo AJ: An evaluation of colorectal endoscopic mucosal resection using high-magnification chromoscopic colonoscopy: a prospective study of 1000 colonoscopies. Endoscopy 2004;36:491-498.

59 Suzuki S, Chino A, Kishihara T, Uragami N, Tamegai Y, Suganuma T, Fujisaki J, Matsuura M, Itoi T, Gotoda T, Igarashi M, Moriyasu F: Risk factors for bleeding after endoscopic submucosal dissection of colorectal neoplasms. World J Gastroenterol 2014;20:1839-1845.

60 Metz AJ, Bourke MJ, Moss A, Williams SJ, Swan MP, Byth K: Factors that predict bleeding following endoscopic mucosal resection of large colonic lesions. Endoscopy 2011;43:506-511.

61 Burgess NG, Metz AJ, Williams SJ, Singh R, Tam W, Hourigan LF, Zanati SA, Brown GJ, Sonson R, Bourke MJ: Risk factors for intraprocedural and clinically significant delayed bleeding after wide-field endoscopic mucosal resection of large colonic lesions. Clin Gastroenterol Hepatol 2014;12:651-661.

62 Gong W, Liu SD, Zhi FC: Endoscopic submucosal dissection for colorectal laterally spreading tumors. ZhongHua Xiao Hua Nei Jing ZaZhi 2012;29:255-258.

63 Shono T, Ishikawa K, Ochiai Y, Nakao M, Togawa O, Nishimura M, Arai S, Nonaka K, Sasaki Y, Kita H: Feasibility of endoscopic submucosal dissection: a new technique for en bloc resection of a large superficial tumor in the colon and rectum. Int J Surg Oncol 2011;2011:948293.

64 Suh JP, Youk EG, Lee EJ, Lee JB, Lee IT, Lee DS, Kim MJ, Lee SH: Endoscopic submucosal dissection for nonpedunculated submucosal invasive colorectal cancer: is it feasible? Eur J Gastroenterol Hepatol 2013;25:10511059.

-65 Terasaki M, Tanaka S, Shigita K: Risk factors for delayed bleeding after endoscopic submucosal dissection for colorectal neoplasms. Int I Colorectal Dis 2014;29:877-882.

66 ASGE Standards of Practice Committee, Fisher DA, Maple JT, Ben-Menachem T, Cash BD, Decker GA, Early DS, Evans JA, Fanelli RD, Fukami N, Hwang JH, Jain R, Jue TL, Khan KM, Malpas PM, Sharaf RN, Shergill AK, Dominitz JA: Complications of colonoscopy. Gastrointest Endosc 2011;74:745-752.

-67 Hirasawa K, Sato C, Makazu M, Kaneko H, Kobayashi R, Kokawa A, Maeda S: Coagulation syndrome: delayed perforation after colorectal endoscopic treatments. World J Gastrointest Endosc 2015;7:1055-1061.

68 Cha JM, Lim KS, Lee SH, Joo YE, Hong SP, Kim TI, Kim HG, Park DI, Kim SE, Yang DH, Shin JE: Clinical outcomes and risk factors of post-polypectomy coagulation syndrome: a multicenter, retrospective, case-control study. Endoscopy 2013;45:202-207. 